\title{
The Semiotics of the Visuals, Songs, Dances and Music: Analysing Aesthetics of Indian Cinema with Reference to 3 Idiots, An Adaptation of Chetan Bhagat's Fiction Five Point Someone
}

\author{
Dr Niteen Vasant Dandekar
}

Assistant Professor of English, DDSP Arts, Commerce and Science College, Erandol, Dist Jalgaon, Maharashtra, India

\begin{abstract}
The present paper is in the form of a humble attempt, on the part of the researcher, to explore the possibility of analyzing the Aesthetics of Bollywood Cinema by looking at the selected film adaptation with Semiotic perspective. After defining the terms 'Semiotics', and 'Mise-enScene Analysis', he aims at deciphering Aesthetics of Indian Cinema. Here the terms 'visual design', 'signs and codes', 'symbols', 'metaphors', 'discourse-words and phrases' and other compositional elements in the film are discussed elaborately. Great care has been taken, here, to avoid the film jargon. He refers to the established conventions as socio-cultural norms prevalent in the film industry in India. This is followed by the in-depth analysis of the selected film. Here the researcher takes into consideration the use of images, video intake of the song, the linguistic connotations of the song, melody element, the get up of the character, dresses and costumes, musical scores, and their linkage with the narration in the film
\end{abstract}

Keywords

Semiotics, Visuals, Songs, Dance, Music and Aesthetics.

Article Received: 10 August 2020, Revised: 25 October 2020, Accepted: 18 November 2020

\section{Introduction}

\section{Historical perspective}

Songs and dance numbers are an inevitable part and parcel of the Bollywood film World right from the days of Alma Aara, the first talking film, the dances from 40's to 60's represent the golden era when melody did enter into the film industry. Rachel Dwyer hits the nail on its head while stating thus:

"There should be five to eight songs to mark nodes in the narrative, such as meeting, falling in love, union, and separation and so on. Many romantic films end with the promise of happily ever after, but the key romantic moments are often those of sorrow and sadness. Love imagined, or love lost, makes the film more emotional. The songs of sorrow ('dard bhare geet') produce longing that was celebrated in Indian aesthetic theory as 'vipralambha shringara' - love in separation. For romance, tears should flow beautifully and often" (Dawyer, 2015, p.1).

During these decades there were many films which became popular on account of the songs. Many songs received the honour of being awarded silver disc and golden disc for the sake of 25000 and 50000 gramophone records. The first song that was awarded the platinum disc for the sake of 75000 gramophone records for the song in Kurbani Aap jaisa koi jindagi me aaye to baat ban jaye, sung by Alisha Chinoy and filmed on Zeenat Aman and the Amjat Khan beat the drum beats in the presence of Firoz Khan. This shows how Songs and Dance numbers are very significant in the Bollywood industry right from the beginning. The same trend seems to continue till today in the form of the five songs in the 2003 super hit film 3 Idiots.

\section{Semiotics and Semiotic Considerations}

Different approaches to the study of literature in English have their own use and validity in the field of literature and criticism. The researcher opts for Semiotic analysis which he is going to apply to the target text (the film adaptation) which functions as the primary data. Semiotics is the study of signs. It involves theory and analysis of signs codes and signifying practices. Semiotics is the study of sign processes (Semiosis) sign and symbols or signification of communication. It is usually divided into three branches entitled Semantics, Syntactics and Pragmatics. Every text is a sign system and text emphasizes on internal structure and thus does not reflect reality but rather constructs it. A set of sign is known as codes and every code carries meaning.

\section{Signs and Codes}

The smallest units of meaning in semiotic analysis are signs. Dressing pattern of the cast in film informs and helps viewers to know and decode the person his character and socio-culture context. Meaning has two levels. On its most basic level, the sign denotes literal meaning. But when a sign occurs in a group or in a particular context that becomes a code, and it can suggest or connote extra meaning. For instance, the colour red simply denotes a colour, but in a specific context, it can connote emotions like anger or love. Such codes are often used in media to reinforce, subtly, the way viewers should think about certain things. These codes are dominant ideologies of culture. They are groups of signs, and these fit together naturally, and they create meaning together. 


\section{Filmic Code}

For the semiotic analysis of film, there are four types of signs and codes. Firstly, Indexical Signs are the most basic of signs in film. It points to a certain meaning -they act as cues to existing knowledge. A ringing bell means the end of class. This type of use of signs is prevalent and constant in all types of media. Secondly, Symbolic codes often denote something they have nothing to do with at first glance, but only because the code exists and because we use them in socio-cultural context. The red heart symbolizes love. Thirdly, Iconic Signs and Code is the literal signs and codes which meant to appear like the thing and they always represent more than just the thing itself. Seeing college student, associates with a hobby, learning, friendship, and discipline and funny activities in the college campus life. It reinforces the ideas we have about these concepts in our culture and reinforces the ideological meaning of those concepts. Fourthly, Enigma Code is an essential type of code used in the film to create a question to which the film "text" then goes on to answer. These are often used in trailers and posters of the movies which make viewers wonder and make them curious to go to see the movie. Lastly, in films, the use convention is conventions are the established, accepted socio-cultural norms as mentioned below:

"Culture is very important in the way we interpret signs and codes. It is important to realize that culture always determines the meaning a sign or code communicates. Your interpretation of a Bollywood film, if you're from the West, will likely be different from the interpretation of someone from that area of the world" (Manon De Reeper, 2016, p. 4). Conventions are often used to shape viewers thinking about a character or event. When it comes to the characters, conventions can easily turn into the stereotypes.

\section{Research Methodology}

\section{Film Analysis and Semiotic Analysis}

Film Analysis is the process in which a film is analysed in terms of Semiotics, Narrative Structure, Cultural Context and Mise-en-Scene, among other approaches. Analysing the film like analyzing any form of literature (Drama, Poetry, Fiction, Poetry etc.) is a form of rhetorical analysiscritically analyzing and evaluating discourse, including words, phrases and images. Semiotic analysis is the analysis of the meaning behind signs and symbols, typically involving metaphors, analogies and symbolism. Semiotics can be applied to anything which can be seen as signifying something.

\section{Analysis of Visuals, Sound, Music, Songs and Dances in 3 Idiots}

Song One: Baheti Hawa Sa Tha Wo: (Disc-1 Running Time: 08:25 to 10:52 Min.)

The first song of the film is Baheti Hawa Sa Tha Wo. This song begins with the mountainous terrain and the thick greenery of the forest of Simla. There are three persons in the car, they are Farhan, Raju and Chatur, the three friends and who are in search of their friend Rancho, with whom they have no contact for the last ten years and they have missed him all this time. Chatur had a bet with Rancho about success after ten years. He has come from America. In this bet, he is quite confident that Rancho will not stand anywhere in comparison to him. They describe him as the breeze of comfortably floating wind in the forest of Shimla. This song is not sung by the protagonist, but it is he who is described in this song written by Swanand Kirkire, sung by Shaan and Sonu Nigam and the music is composed by Shantanu Moitra. Where is that breeze of cold wind? is the question that is haunting Rancho's friends. This question is repeated and echoed in the song. The other questions about the protagonist are where had he come from? And where had he gone? In this respect the protagonist has remained an enigma.

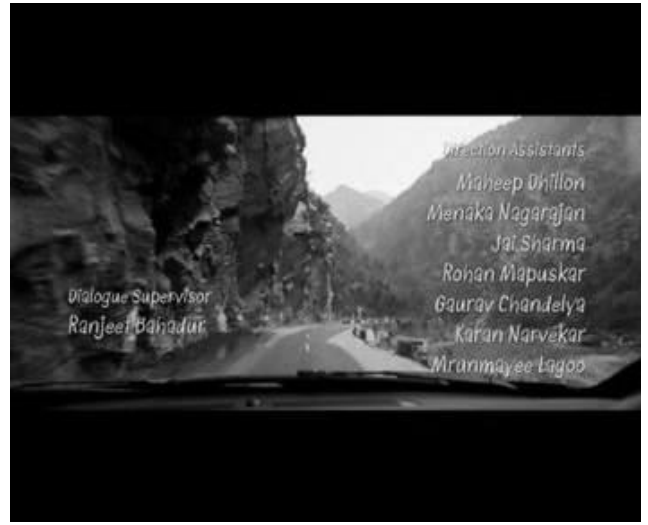

Fig.1 Screenshot of Shimla Mountainous terrain, River, Road and Sky from the film, 3 Idiots, 2009, Hirani R.

The semiotics of the first song is the breeze of nature and the primetime in the company of nature, the Himalaya forest and the open sky. The visual is that of the open sky, the forest, winding mountainous road and the red colour mechanical vehicle SUV. The sounds in the song are the singer's contribution. It is the song sung in the background of the beauties and glories of nature and the splendour and grandeur of the blue sky. It is not known who is singing the song; the lyrical words express the feelings that the three friends have in their minds. They have understood that they are in search of a grand noble aim, something more sublime and something more spiritual. This song is not accompanied by dancing. What is therefore significant in this song is its visual presentation and the melodious tune rendered musically, and is studded with the highly lyrical expressions.

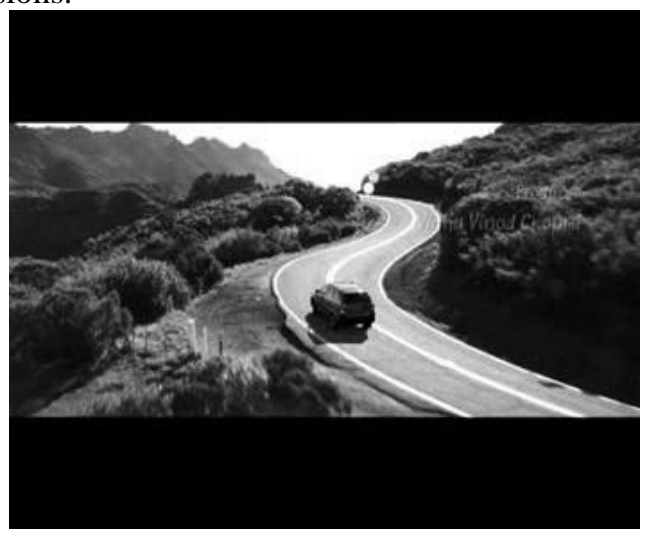

Fig.2 Screenshot of Shimla Mountainous terrain, Sky, Road and Volvo Red SUV from the film, 3 idiots, 2009, Hirani R. 
The lyrical effects are highlighted by the imagery used in the song. On one hand the use of nature imagery is made on the other the sensuous imagery is used. The image from nature breeze of wind, Awara Badal (Wandering Cloud), Udati Patang (Flying Kite), Registan me Gaav (Sheltering village in a desert), Ghav per Marham (Balm on the wound) are the images which have appealed to the senses of sight, hearing, smell, touch. All these are skillfully woven in this song. This song is not accompanied by dancing and also it is not sung by any of the characters on the screen.

In the first song of the film, the visuals of Himalaya mountainous have a socio-cultural and geographical association with India. Rounding roads and the running SUV are the symbolic visuals of the journey and the search of a missing friend. The selection of name for the friends Ranchoddas, Farhan, Raju and Joy is the multicultural representation of India. The hilly roads and the gradients symbolically represent the difficult path of finding Rancho. The selection of costume, Raju's Nehru Shirt and sneaker shoes, Chatur's three-piece suit and imported Volvo-SUV in the song are the visuals of Western Influence on metropolitan Indian society. These are the set notions of the elites and elitists culture. Farhan's looking into the infinity expressing of his feelings like soliloquy dramatically connect the plot and story to be continued.

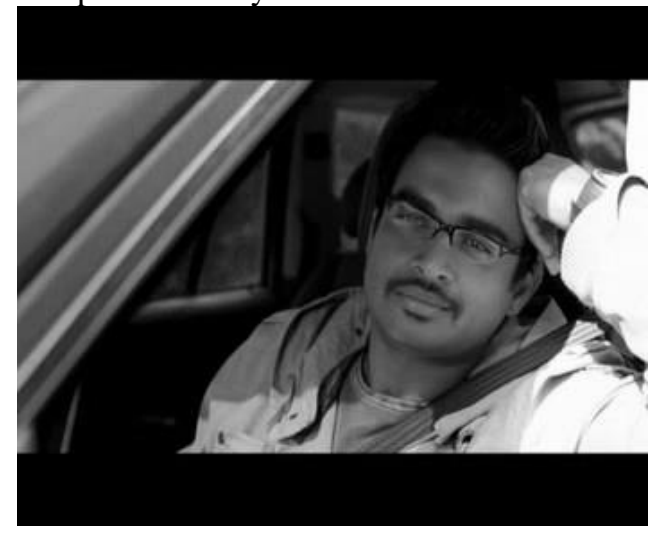

Fig. 3 Screenshot of the Protagonist Farhan entering into the Flashback from the film, 3 idiots, 2009, Hirani R.

Song Two: Give Me Some Sunshine Give Me Some Rain: (Disc-1 Running Time: 28:51 to 30:02 Min.)

The second song is a solo song which is picturized on Ali Fazal who has played the role of Joy Lobo. He is working on the project to be submitted before the stipulated date. He works hard on his project but he is not completely successful. He still has the confidence to succeed in his project. Therefore, he requests to the director Dr. Viru Sahastrabudhhe who is quite appropriately nick named Viru $\mathrm{S}$. as the virus is harmful and detrimental to the progress of any and everyone around him. Viru S. does not permit any extension to Joy Lobo. The frustrated student throws the project into dustbin goes to his room in the hostel and begins to play on his guitar. The musical accompaniment of the tunes on guitar has set the musical score to the second song. It is a sad song. It is a sincere request to give one more chance. It a request to follow a humanitarian rather than a disciplinarian path, but Viru S. has no human heart. The irony of Research Element in the field of Engineering is obliquely represented through this song. That is proved even in the case of his son, whom he does not allow to select the course of his choice. The lyricist of this song is Swanand Kirkire and the music is composed by Shantanu Moitra and sung by Suraj Jagan and Sharman Joshi.

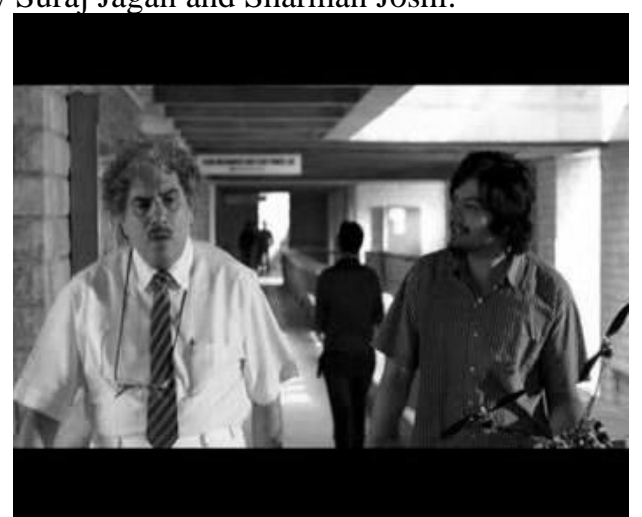

Fig. 4 Screenshot of Joy Lobo Requesting the Director for extension to submit project from the film, 3 idiots, 2009,

Hirani R.

The semiotic tools in this song are Sunshine and Rain. The young boy has been burning all his life till this moment and he was burning in the fire of disappointment because of rejection to submit his project by not granting him some days extension. In order to save himself from the constant and continuous dying every moment as well as burning in the fire he needs some Sunshine some Rain and moreover one more chance to grow up once again. These wishes are simple and straight forward and therefore everybody desires to have a second chance. Giving and taking another chance is not a failure but a step to attain positive and clear success. The second chance is the birth right of every individual but an idiot like ViruS cannot understand this. Students like Chatur pamper his ego and so he feels that all is well in his rotten state of Imperial College of Engineering. The visuals for this song are the playing on the guitar by Ali Fazal, his beard, his strokes on the strings of guitar are the visual moments presented. His sad and sorrowful mood is reflected by the dark and narrow corner of the hostel veranda railing. Darkness has filled the heart of the singer student and darkness has pervaded the entire atmosphere. This is the skill of the cinematic taking of the song which was perfected by Rajkumar Hirani The taking of the film song needs the entire film unit to work in joint collaboration. The words of the song are complemented with the comments made by Sharman Joshi which are quite appropriate. The words themselves refer to dying every moment and without any opportunity to lead life happily and as one desires. In the choice of the career the aptitude of the student is not taken into consideration as in the case of Farhan Kureshi, the same is the situation about Joy Lobo that their parents in particular their fathers want their sons to be moulded in their own cast. They want their aspirations to be fulfilled by their sons. That is why learning is burdensome. Even the father wants to give bribe for the son to score $99 \%$ of marks. Alpha, Beta, Gama and H2SO4 have already wasted their childhood and youth and even the whole of their life that is why the young student who is frustrated demands delightful Sunshine pleasant Rains to grow up once again. Here the tone is quite different. The pessimism in the life of pressurized and administratively dominated students has 
been connotatively made clear through the wording of the song, befitting visuals, metaphorical use of theh "Sunshine" and "Rain", guitar-symbolic of one's own tunes and sense of frustration felt through the stringed modulations of the yearnings for the bright career and thereby fulfilling the dreams of their parents.

The hairstyles of Joy Lobo, his hobby of playing Guitar, in the second song are the visuals of Western influenced metropolitan Indian society and culture. The socio-cultural relationship is noticed in the use of words sunshine and rays meaning warmth and wetness which are needed to make life pleasant one more chance is necessary to shape things again to right the wrong. Except the use of guitar there are few musical instruments like violin and other string instruments which have added to its score. This song is not a dance sequence but it is a highly meaningful lyric echoing the main theme of the film.
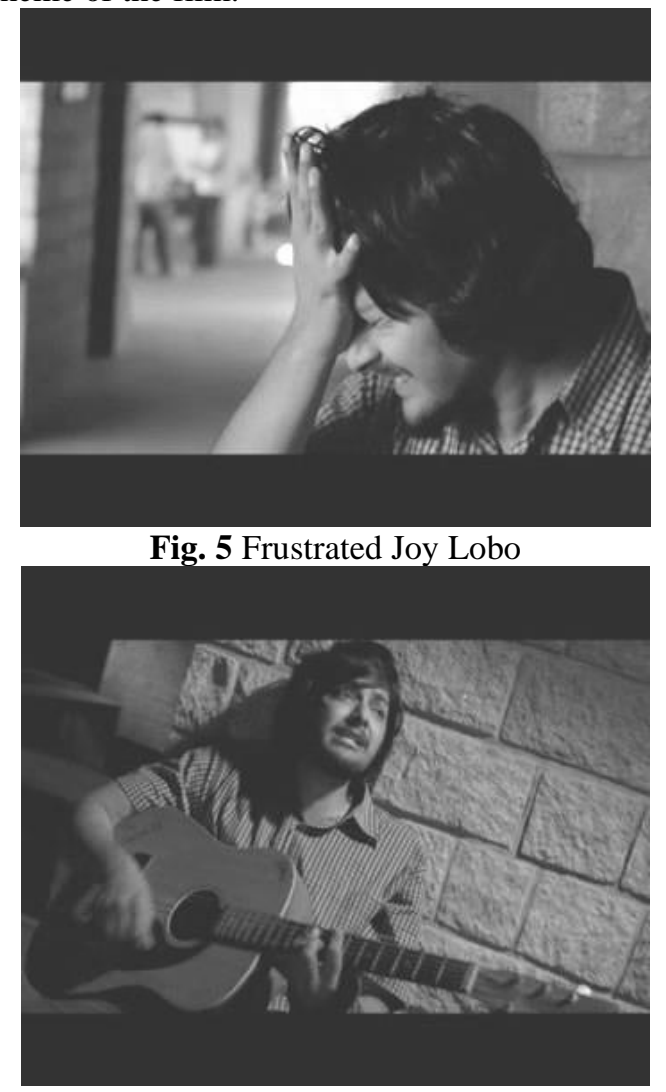

Fig.6 Frustrated Joy sings a song to grow up once again

Fig. 5 and 6 Screen shot of frustrated Joy Lobo singing a song to grow up once again from the film,

3 idiots, 2009, Hirani R.

Song Three: All izz Well: (Disc-1 Running Time: 31:28 to 34:52 Min.)

The third song is 'All izz Well'. In this song there are three types of visuals. In the first few visuals students are gathering and seating in the ICE classroom which are in IIT specific and confused in the shower of knowledge. In the second type of visuals the stopping of the shower and singing and dancing of the students in bathroom expresses hostel life of students. In the third type of visuals we see students gathering, shouting, whistling, singing and dancing together on the steps of the water tank, hostel and on the campus as well. The costumes in visuals Nehru Shirt, Jeans,
T-Shirt, Tie, and Shorts and so on are symbolic of the Western influenced metropolitan Indian society filtering down that culture. Center semiotic of this film 'egg' is also shown in by M.M. in this song.

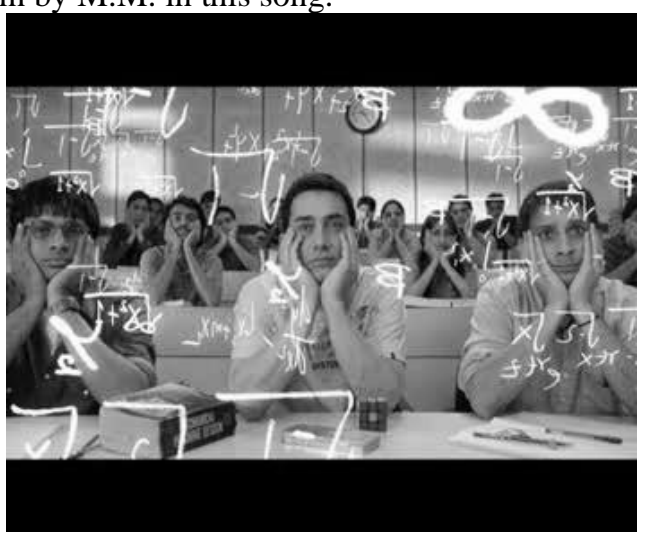

Fig. 7 Overburdened \& confused study environment

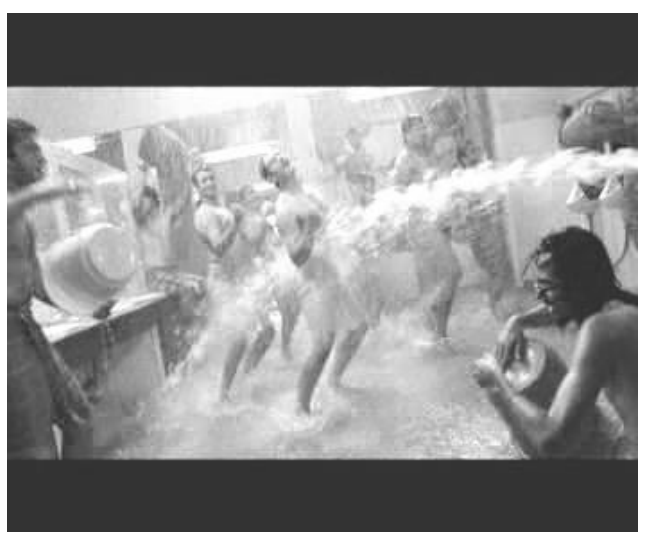

Fig. 8. Bathing also becomes joyful moment

Fig. 7 and 8 Screen shot of over burdened and confused study environment where bathing also becomes joyful moment from the film, 3 Idiots, 2009, Hirani R.

The song does not have words from any other but the remaining four songs are repeated with English words. The third song is All izz Well which is a musical number, it has All izz Well, Egg, Hen, Omelette, and many such English expressions. The same is the case about Zoobi Doobi. The semiotic expressions in this song are the egg and its uncertain future. All izz Well is the message which is given through this song and dance number which is sung in chorus and a continuous group dance of hundreds of students. Rancho is in the bathroom. He is taking a shower but the shower stops therefore rather ironically and satirically he begins to sing All izz Well when in reality all is not well. The education system is rotten; the students in schools, colleges and in the universities are treated as eggs. Their future is uncertain. They do not know what is stored in their future as egg has no power to know whether it will be fried, boiled, half-fried, or cooked as an Omelette. This uncertainty is a characteristic feature of modern education system which does not guarantee any solid successful career for the students. In Tare Jamin Par and in 3 Idiots the same theme of choice by aptitude is emphasized. This is very important but even today this area of career guidance and aptitude counseling and the choice of the course are the areas which are not being taken into serious consideration. 
Some preliminary steps have been initiated but in a country like India in which about sixty crores of young men and women need guidance and counseling these arrangements are inadequate. This is the theme of the film and the theme of the song which is echoed repeatedly in the three monosyllabic words All Izz Well, Singing and dancing, the throwing of water, jumping around the bathrooms, in the passage, then in the open campus is highly artistic. The ironic line 'All izz Well' paradoxically hints at the grassroute reality that "NOTHING IS WELL" or Nothing at all is up to mark. This reiteration of the stark reality in the field of education does have the hammering effect on the minds and hearts of the reader-spectators tho take the song All izz Well song as the commentary of 'the critique' on Indian Educational System especially on the field of Engineering. This song does not have musical score as such because the singing and dancing occupies the central position. Therefore, the music director has preferred to remain silent. The sounds of the taps, chairs, pipes, beating of the steps, have provided natural music as was the case with the music given by Music Director Vasant Desai as in many of $\mathrm{V}$. Shantaram films. All Izz Well reflects the song which washes out the mood of depression and gives a message of positive optimism. The message is to find solution when there is confusion in life, and when life is out of control. This is the longest song in the film

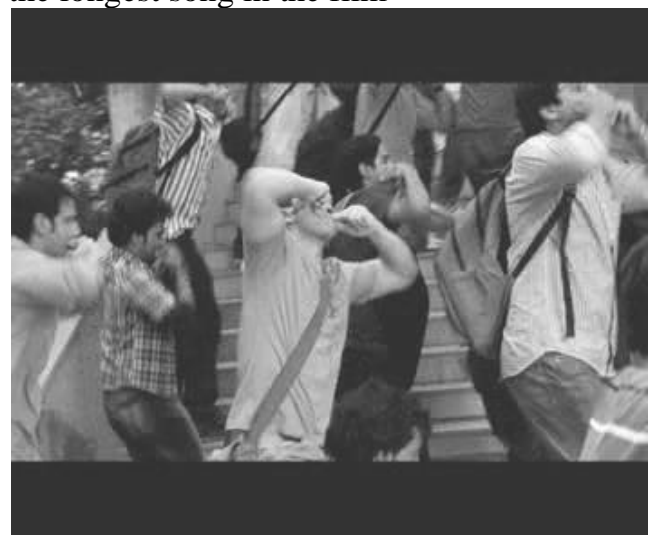

Fig. 9 whistling on the Water tank staircase

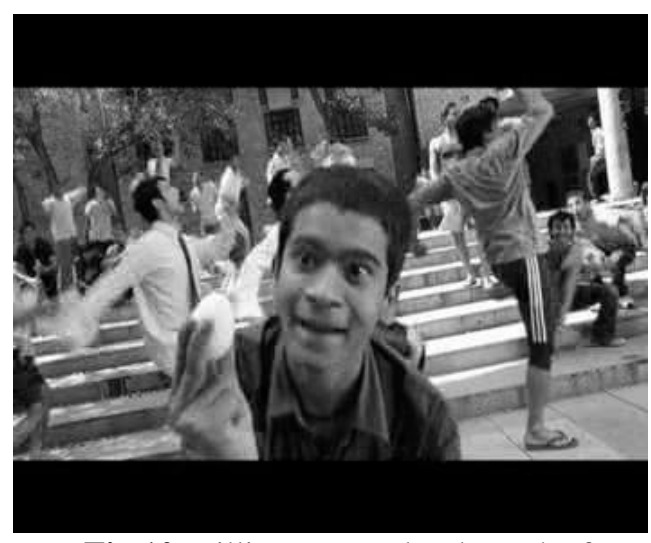

Fig.10 Millimeter speaks about the future of an Egg

Fig. 9 and 10 Screen shot of whistling students and Millimeter questions about the future of egg from the film, 3 idiots, 2009, Hirani R.

The dance sequence of the All Izz Well is a community activity. The three words are magical and they hypnotize all the students in such a manner that everybody joins and dances and dances in a free style. The symbolic chairs are used in which the three idiots seat and give a sermon of wisdom and righteous path. The messages of Lord Krishna, Lord Buddha, Lord Christ, and Prophet Mohmmed are combined in this most favourite song and dance number of the film 3 idiots.

The tears and smiles, the disappointments and hopes, sorrows and joys are linked when the twin songs Give Some Sunshine runs on Disc-1 running time: 28:51 to 30:02 Min.) and All Izz Well runs on Disc-1 running time: 31:28 to 34:52 Min. All Izz Well is a positive reaction to the negative mood of Give Some Sunshine where Rancho finds solution for Joy Lobo's project.

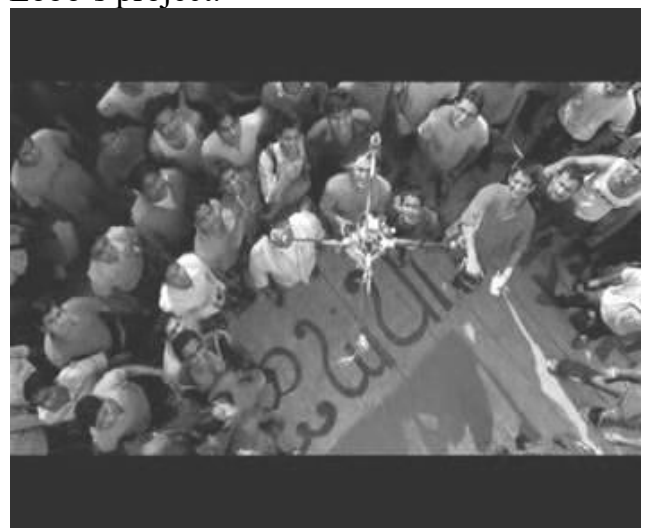

Fig. 11 Rancho's success in Joy's project

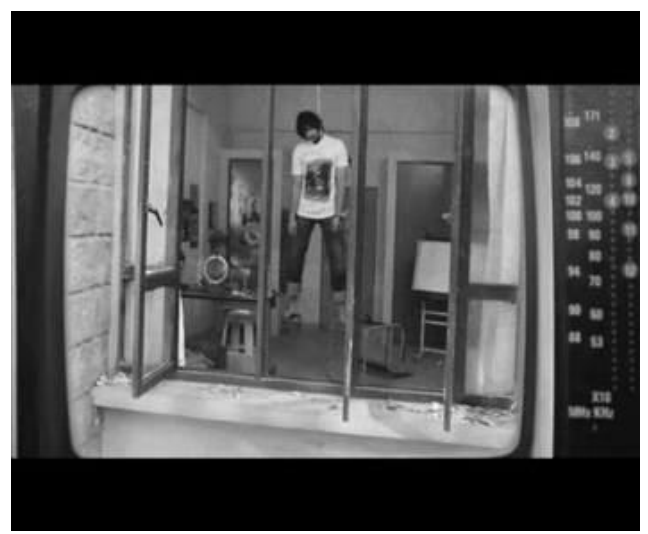

Fig.12 Joy's project shows Joy’s suicide

Fig. 11 and 12 Screen shot of Rancho's success in Joy's Project and exposes Joy's suicide in his own project from the film, 3 Idiots, 2009, Hirani R.

Though the project remains successful unfortunately the first flight of the project shows Joy Lobo hanging as he has already committed suicide in his room due to utter depression. Sad mood is changed by All izz Well and the joyful mood of All izz Well is again saddened by the suicide of Joy Lobo.

Song Four: Zoobi Doobi: (Disc-2 Running Time: 09:58 to 14:14 Min.)

Meanwhile on their visit to Farhan and Raju's home in response to Director's letter they are denied food at Farhan's house which Raju's mother offered but due to situational nausea they keep their dinner incomplete and join marriage feast for the dinner. Fortunately Rancho meets here Pia for the first time, but unfortunately they are caught red handed 
as uninvited guest by Pia and Viru S. as it was a marriage of Mona. Here Pia was greatly impressed by Rancho's style of explanation and demo.

Raju's father is serious in that case Rancho's appeal to Pia to help in the situation and uses her scooter as ambulance has brought them together and close to each other. Apart from that Rancho helped her to know the personality of Suhas (Price Tag) to come out of his relationship. So they naturally come close to each other and as Bollywood films demand here in 3 Idiots also a love story of Pia and Rancho begins. In the beginning of this story is the Fourth song of the film. It is a dream sequence. The song begins as if entering in the mind of Pia and as she is in love, she sees Rancho everywhere while on the other hand ViruS hates Rancho he also sees him everywhere. The semiotic connotations used in this song are many.

Love is the best. Love conquers all. Amor vincit omnia is Amor (love) vincit (wins) omnia (all)- Love wins all. It is difficult to imagine Bollywood film without love story and 3 idiots is not an exception to it. David Courtney also agrees that:

"let's talk about the performance art. In "3 Idiots", there are scenes of songs and dancing, which are significant in Indian cinema, no matter what genre or story plot it is. According to David Courtney, no Bollywood film would be complete without a song and dance between the hero and heroine. When Pia falls for Rancho, she imagines herself singing "Zoobie Doobie" and dancing in duet with Rancho. Meanwhile, having a group of dancers dancing the classical or folk dance with the main character(s) is also a signature part of Indian films" (Courtney D, 2012, p. 1).

The visuals of the forth song validates the point. Natural growth of love in Rancho and Pia, her feeling of falling in love while seeing snapshots of her sister's marriage results into Pia seeing Rancho everywhere. It is a dream sequence song and the entry of the hero is like an angel.

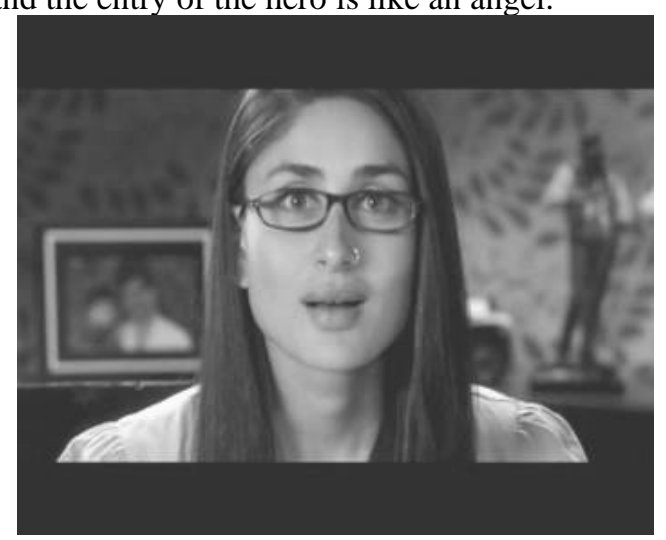

Fig. 13 Piya enters into flashback

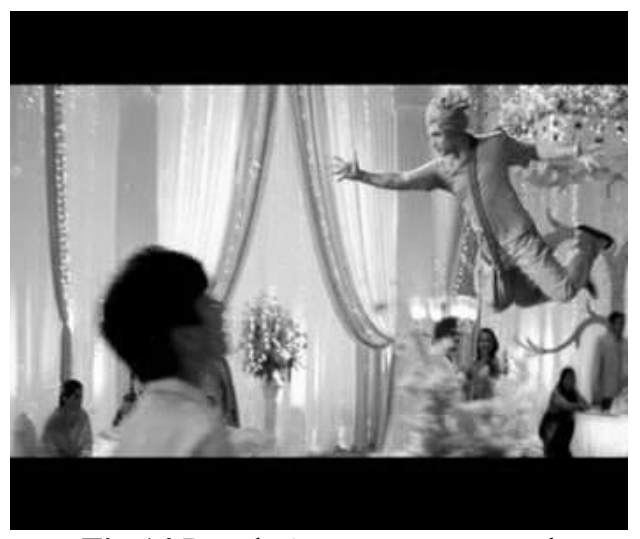

Fig.14 Rancho's entry as an angel

Fig. 12 and 13 Screen shot of Piya's flashback and Rancho's entry as an from the film, 3 Idiots, 2009, Hirani R.

The decoration of the marriage hall and the costumes of Pia and Rancho have direct relationship with Indian Culture. The feeling of love and over joy results into dancing in the rain, moonlight and so on. In this song the visuals of Astrologer Baba, Hanumanji are socio-cultural visuals linked with belief and belief in religion, The costumes of the Cook and News Anchor and Pia are Western influenced metropolitan Indian society and a new culture. The dances used in this song are influenced by Indian Classical, and Western Ball Dance.

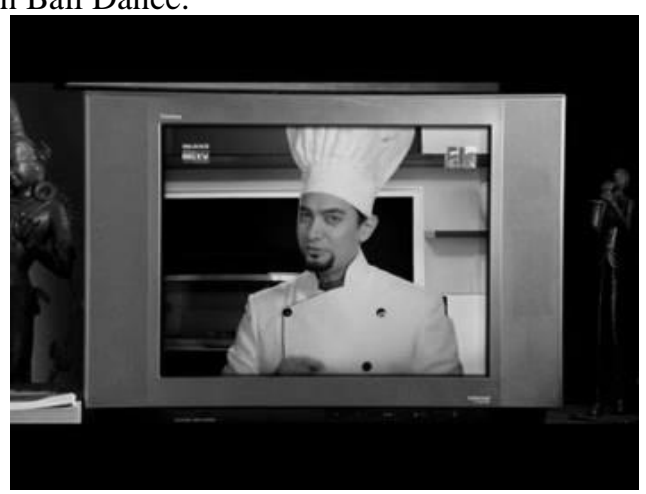

Fig. 15 Piya sees Rancho as chef

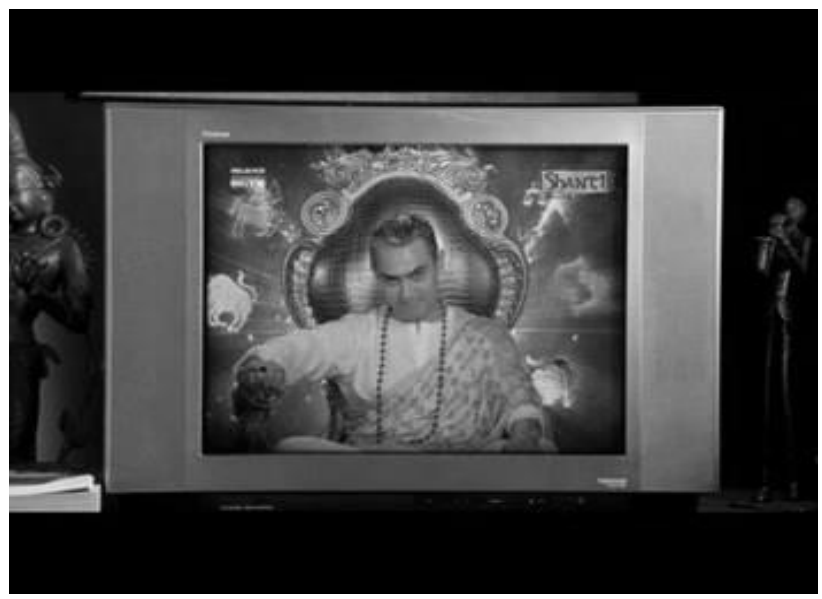

Fig. 16 Piya sees Rancho as Astrologer 


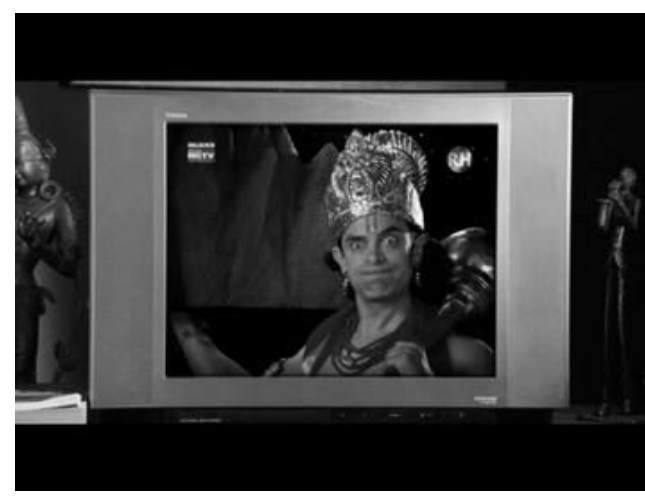

Fig. 17 Piya sees Rancho as Hanumanji

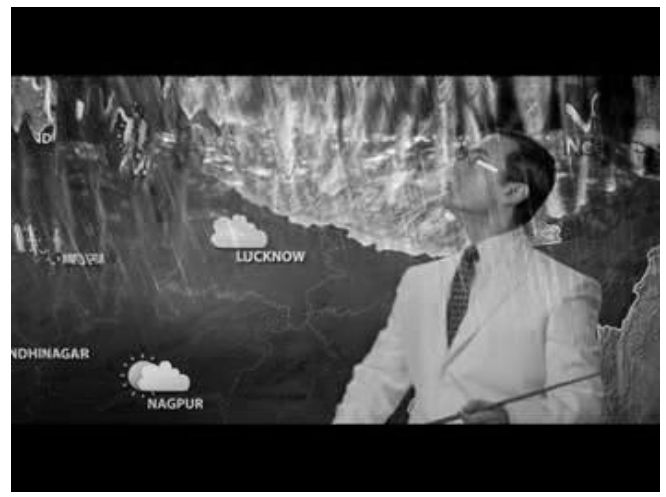

Fig.18 Piya sees Rancho as Whether Reporter

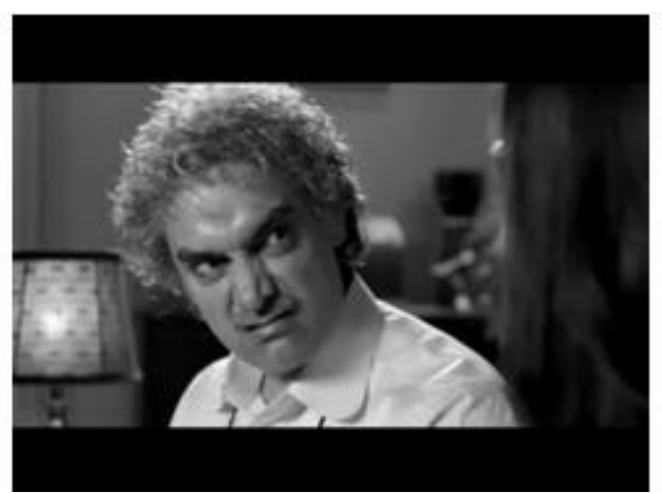

Figure 19 Piya sees Rancho in her Father

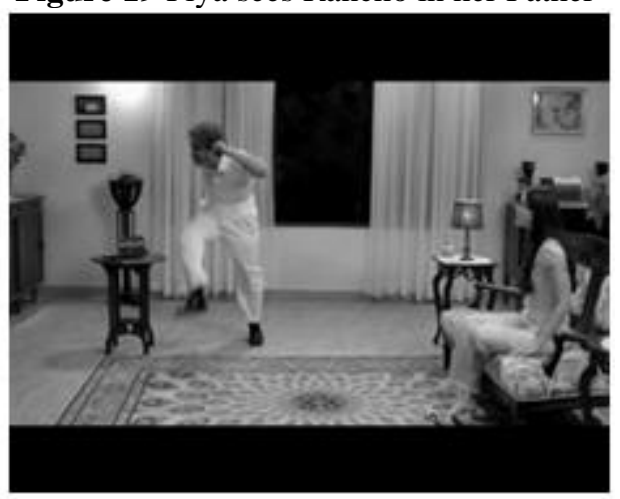

Fig. 20 Imagines father dancing

Fig. 15, 16, 17 and 18 Screen shot of Piya's day dream to see Rancho everywhere as Chef, Astrologer, Hanumanji, Whether reporter even in her father from the film, 3 Idiots, 2009, Hirani R.
The singing of lips, the bees the Sun rays the words are singing and so the lovers are making talks in whispers. The next stanza introduces the rain and the wet sari of the heroine, and then come the moon and the stars.

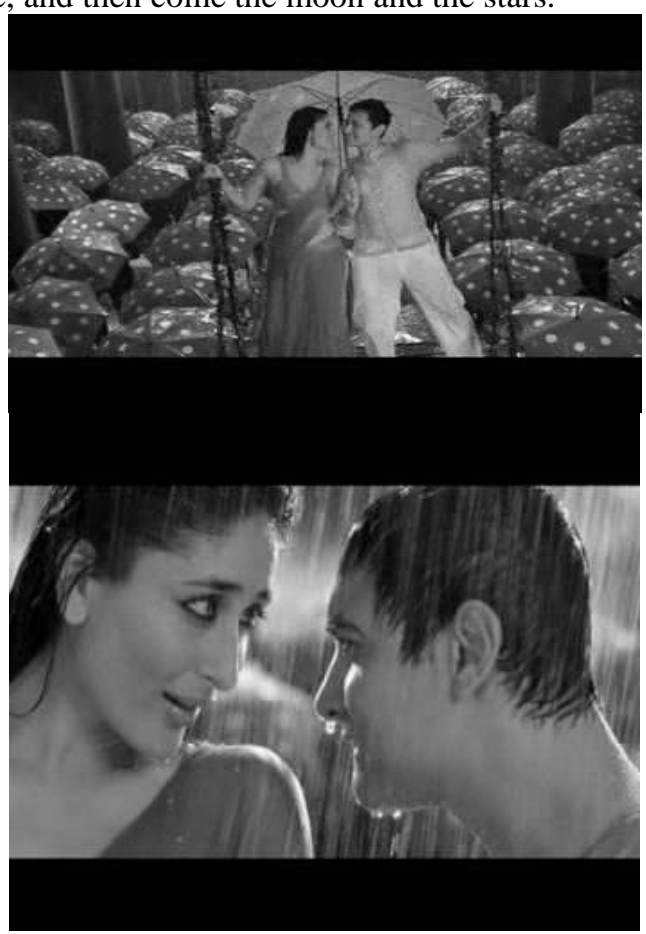

Fig 21and Fig.22 Indian Duet Rain Dance

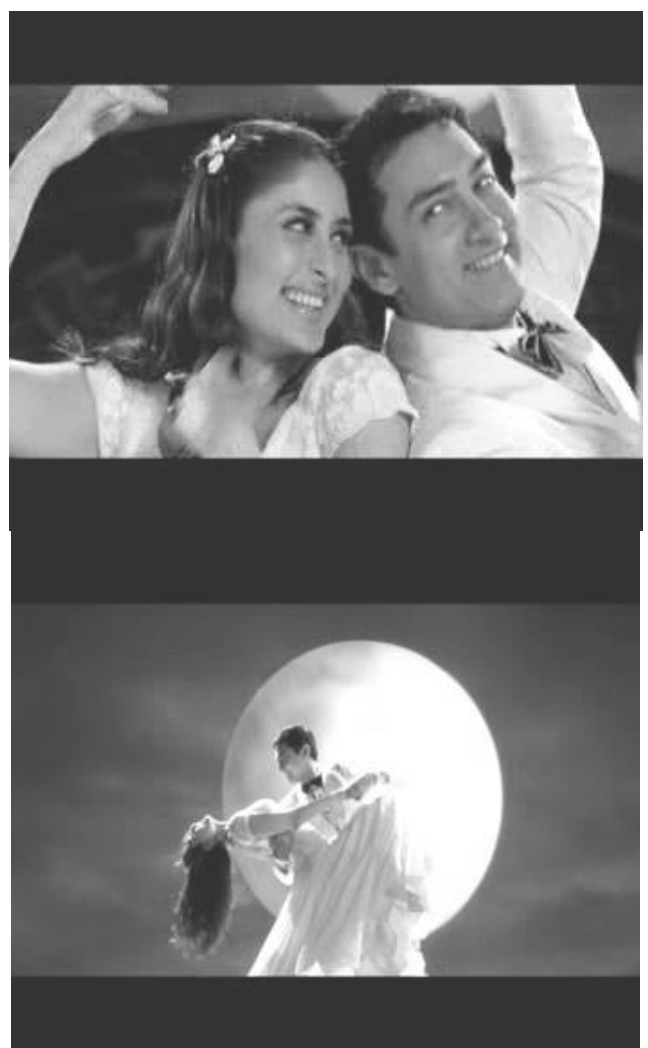

Fig. 23 and Fig.24 Piya \& Rancho in a classical duet and Ball Dance in dream

Fig. 21, 22, 23 and 23 Screen shot of the Indian Rain Duet Dance and the Classical Duet Ball Dance from the film, 3 Idiots, 2009, Hirani R. 
The words of the song are repeated. The lyric begins with the three lines which state that the breezes, the sky, the entire universe is singing. Then there are four lines in which the expression Zoobi Doobi is repeated. Twelve times the six lines have Param Param which is repeated thrice. The expression Nache Qyu Pagal Suupid One is repeated at the end of the fourth line of every stanza. Jaisa Ki Filmo Me Hota Hai the same is shown to be happening incidentally and the does have the hammering effect on the minds and the hearts of the spectators. This song begins with the memories of marriage feast on the occasion of Mona's marriage and turns Rancho and Pia into bride and bridegroom costume to dance freely as lovers in the retro sequence songs.

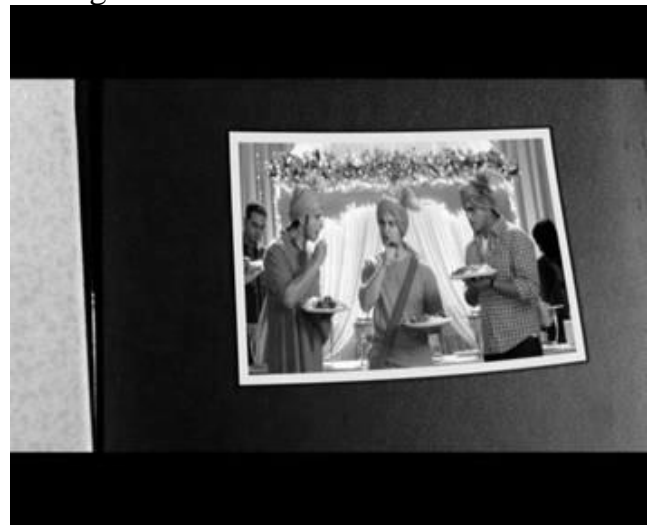

Figure 25 Memories of marriage feast

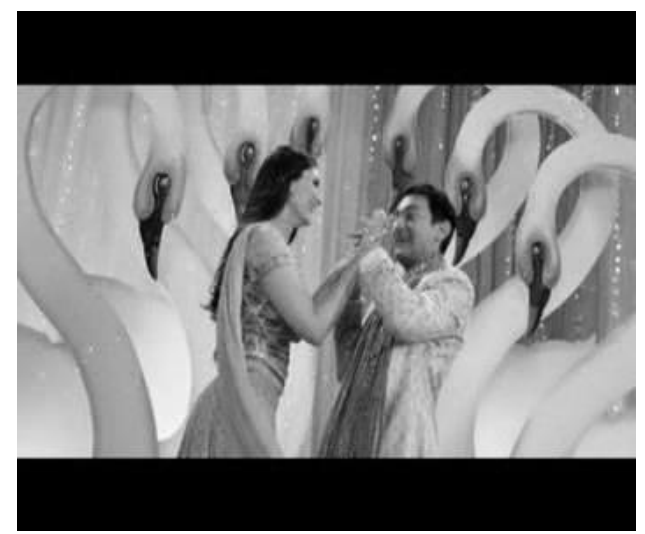

Figure 26 Indian Bridegroom costume and duet dance

Fig. 25 and 26 Screen shot of Memories of marriage feast and duet dance in Indian Bridegroom costumes from the film, 3 Idiots, 2009, Hirani R.

But the song and dance number here is a brand new twenty first century dream love song. The first three lines of the second stanza tell about the rain. It is the replica of the famous song in Shri 420 entitled Pyar Hua Ikrar Hua. There was only a single umbrella but here are many umbrellas. The first three lines of the next stanza in the song introduce the studio Moon in the studio Sky as they do not want to be lonely they must come together as a Tim Tim Star. This song has presented two songs from Aawara first Dum Bharke Chanda second Mai

Tumse Pyar Kar Dungi and the dream sequence of its kind in Hindi films is Aajare Pardeshi which is presented on the similar set. This song and dance number is highly delightful because of its artistic technique by the director. The Director
Rajkumar Hirani has made use of visual presentation of marriage feast, rains and dream sequence through the director's cut. While doing so the director, the actors and the team of all the members of the Film Making Department have presented the sugar-coated Five Point Someone in it's better version. It shows that in the field of Engineering, in grading, even 0.5 is almost equal to zero. Therefore, that person who has a score of 0.5 has no place in the society. He cannot progress and cannot prosper too.

Song Five: Jane Nahi Denge Tuze: (Disc-2 Running Time: 09:58 to 53:47 Min.)

The fifth song is Jane Nahi Denge Tuze. This is the melancholic song of all the songs in 3 idiots which brings tears to the eyes of one and all. This song has lot of impressive visuals. Raju is unable to bear the threats and pressures of the Director Viru S. So, he jumps from the Director's office window to attempt suicide. As he falls down the window students on the campus along with his friends Rancho have gathered and noticed the pool of blood. Frantically they begin to take him to the hospital. Rancho is riding a scooty and directing the vehicles to give way to the hospital.

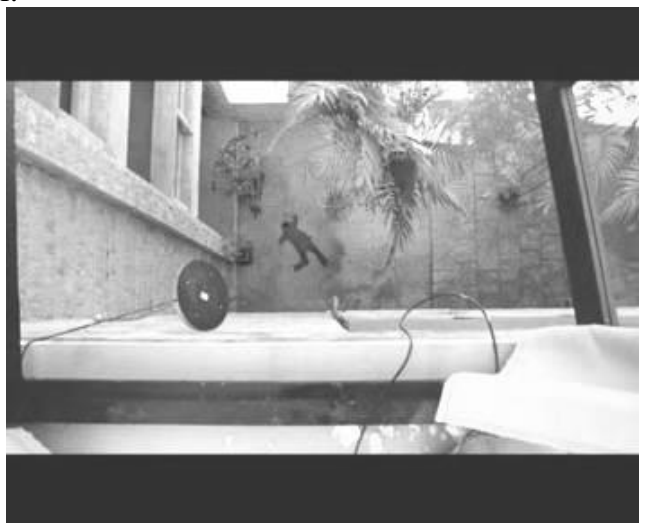

Fig. 27 Raju Jumps from Director's Office

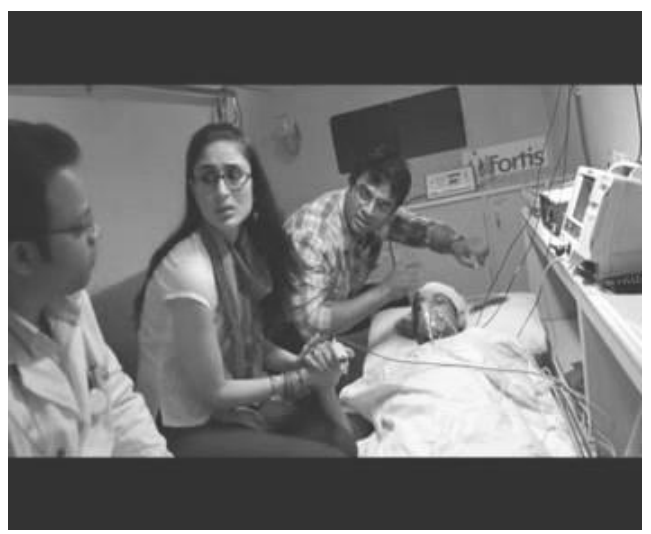

Fig. 28 Farhan and Piya Carrying Raju to the Hospital 


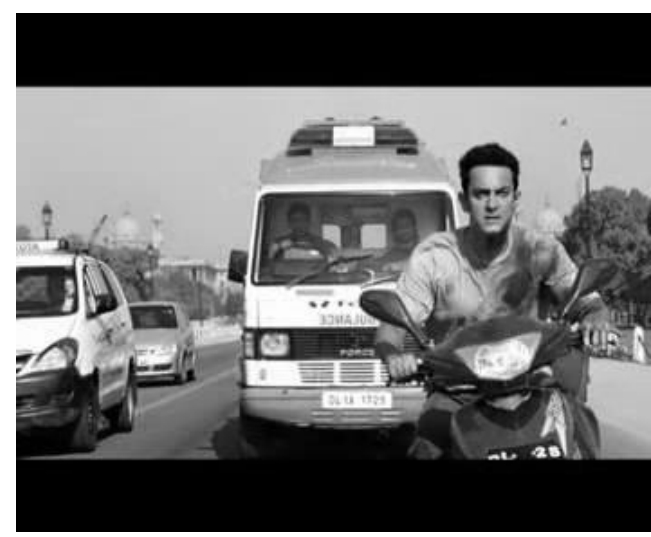

Fig. 29 Rancho on scooty directing vehicles

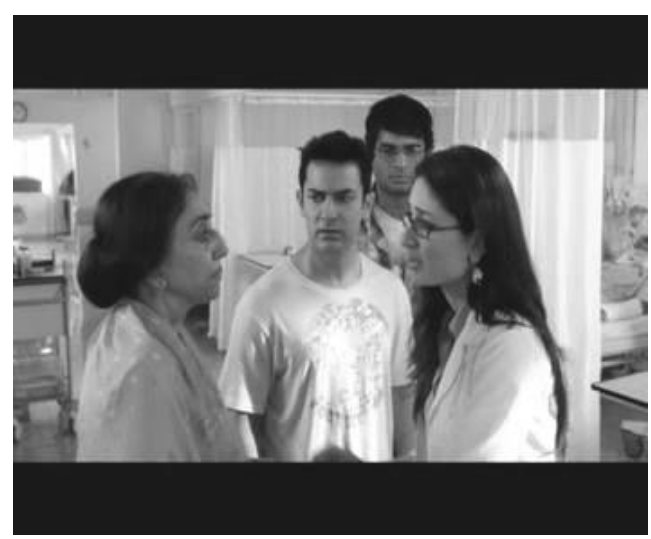

Fig.30 Raju's mother and friends

Fig. 27, 28, 29 and 30 Screen shot of Raju's jump from the Director's office, his friend's caring him to the hospital and his friend's soothing his mother, from the film, 3 Idiots, 2009, Hirani R.

But before that they have even challenged God saying that God may attempt to claim Raju but his friends and well wishers like them state that they are not going to be afraid of even God. They are standing and blocking the path of death. Life is short but why do you tremble even in the first step, listen to your friends. The night of sorrow will pass soon, your mother has blessed that you should live for ages and ages. Therefore put your eyes in our eyes, smile Oh idiot, why do you trouble us. It is certain that we will not allow you to leave your life.

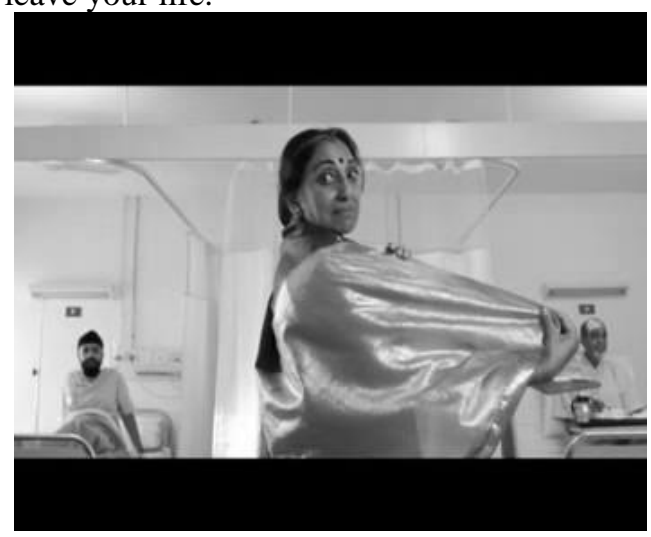

Fig. 31 Raju's mother showing her New Sari

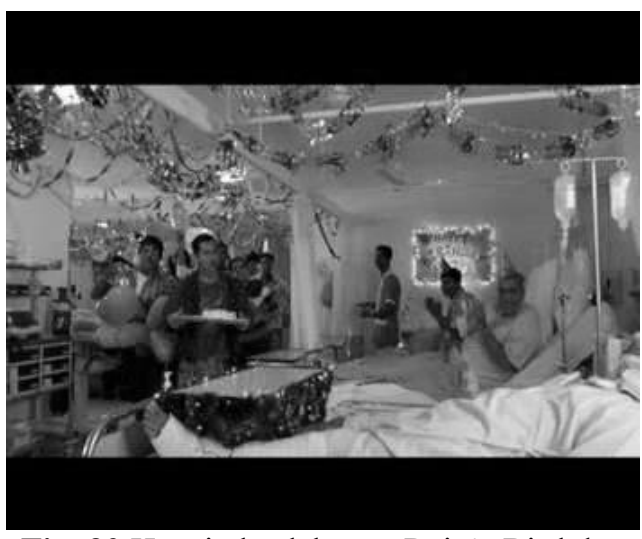

Fig. 32 Hospital celebrates Raju’s Birthday

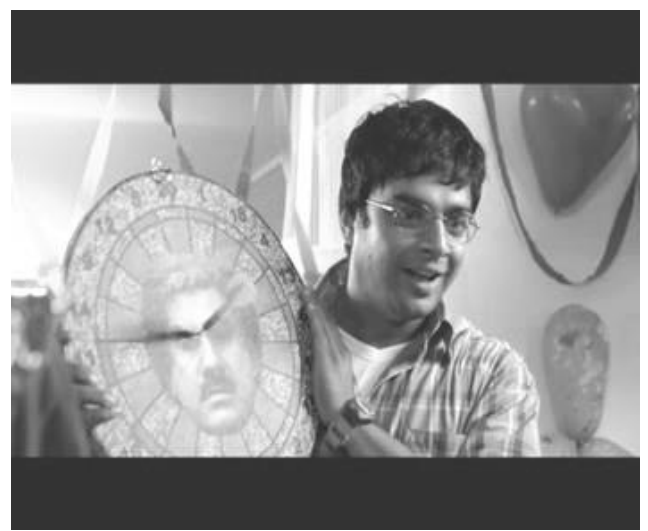

Fig. 33 Farhan and Rancho attempting to smile Raju

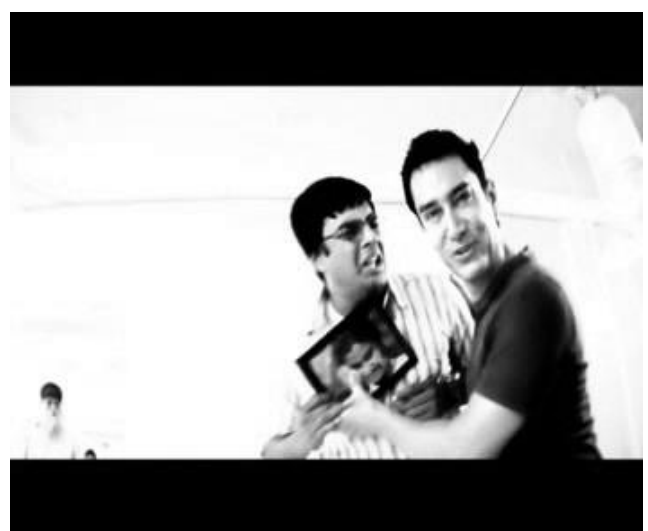

Fig.34 Farhan and Rancho attempting to smile Raju

Fig. 31, 32, 33 and 34 Screen shot of Farhan and Raju's attempt to smile Raju when he was admitted in hospital from the film, 3 Idiots, 2009, Hirani R.

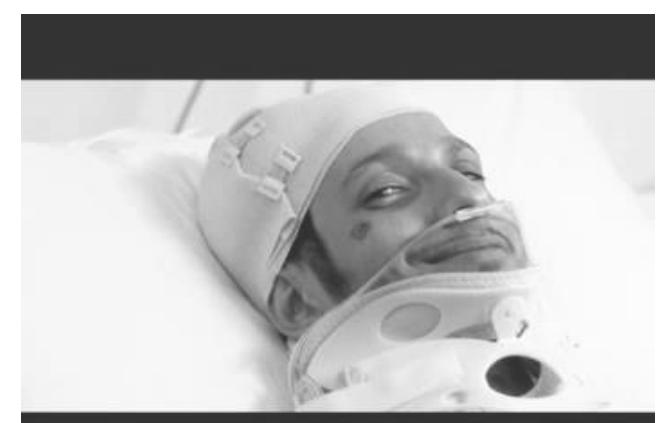

Figure 35 Raju Smiled come out of danger 


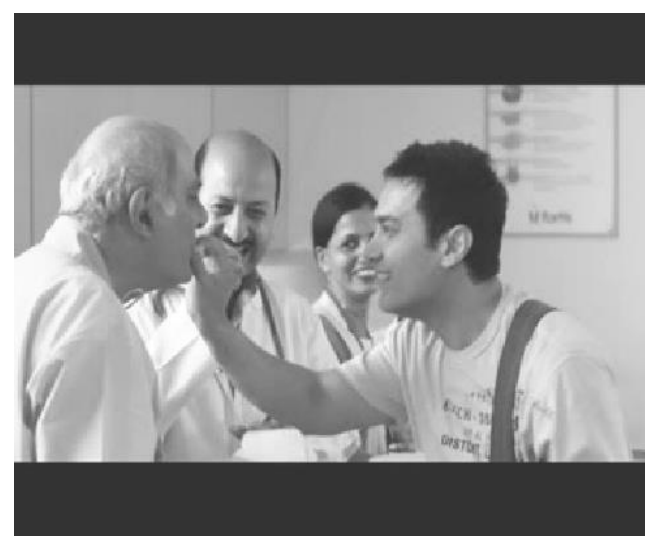

Figure 36 Rancho distributes sweet on Raju's recovery

Fig. 35and 36 Screen shot of Raju's smile- he comes out of dander so Rancho distributes sweet on his recovery from the film, 3 Idiots, 2009, Hirani R.

In the fifth songs the visual of blood pool, Advanced Ambulance, Operation Theatre, ICU section in the hospital, Costumes of Raju's parents Mother's Sari and Father's Inner Wear are Indianised, Westernized dressing of Pia with Eastern Odhani. The costumes of Farhan and Rancho are College Student specific with college bag. Costumes of the patient and nurses are Indianised costumes bearing local colour of presentation.

This song of three stanzas is of twenty six lines alternatively one or two lines are short. This has given a rhythmic pattern. This song runs for a long time. Towards Raju's recovery the smiling and feeding of ladyfingers by the mother is seen. But the celebration and the distribution of sweets change the mood. The song begins with the chill of deadly terror but ends in jubilation. Therefore Raju and Farhan along with Chatur take $U$ turn and begin their journey to take Pia with them to meet Rancho.

Song Three Repeat: All izz Well: (Disc-3 Running Time: 44:11 to 46:40 Min.)

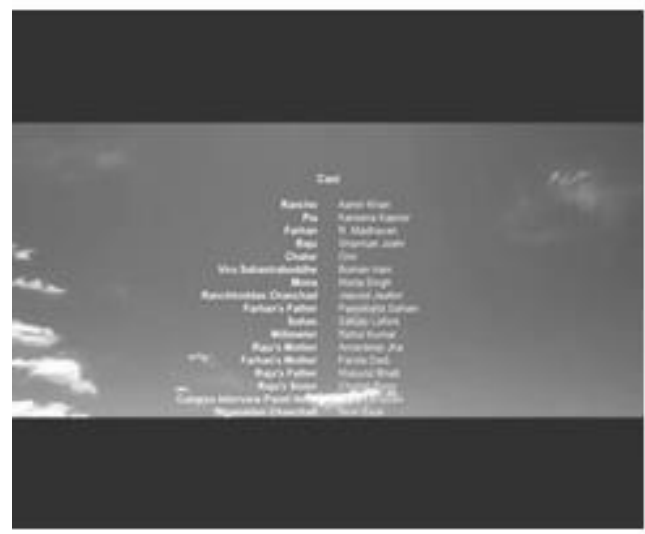

Fig. 37 Screen shot of Credit scrolling on the background of Shimla sky at the end of the movie here song All izz well is repeated from the film, 3 Idiots, 2009, Hirani R.

\section{Results and Discussion}

The beauty of the whole exercise in the field of film aesthetics is that the meaning creation process is a joint process and is not a mechanical process coming from outside. It requires active inner participation on the part of those who are interested in it and the efforts must be deliberate ones where the element of initiative creativity is of prime importance. Chandler Daniel (2003) rightly validates the point when he asserts:

Exploring Semiotic perspectives, we may come to realize that information or meaning is not 'contained' in the world or in books computers or audio-visual media. Meaning is not "transmitted" to us- we actively create it according to a complex interplay of codes or conventions of which we are normally unaware. Becoming aware of such codes is both inherently fascinating and intellectually empowering.

Indian cinema has come to be known the world over by its musical dimension with its songs and dances, which lie at the heart of its cinematic tradition. When the talkie appeared on the Indian scene in 1931, music and song in their theatrical manifestations have been a major source of entertainment for all the classes in all the regions of India. Bollywood Films in general and Hindi films in particular share noticeable features, such as the use of melodrama and heightened emotion, especially around the family, an engaging narrative, stars, usually one of glamour, grandiloquent dialogues and the inclusion of the all important songs.

Almost every Indian film has at least an average of four to six songs. In the era between the 1940s and the 1960s, some Hindi and Tamil films even had up to 20-30 songs. Songs in Bollywood are sung by professional playback singers, rather than actors, who lip-sync the lyrics. Bollywood film music is called filmi music. Songs from Bollywood movies are generally pre-recorded by professional playback singers, with the actors then lip synching the words to the song onscreen, often while dancing. The composers of film music, known as music directors, are also well-known. Their songs can make or break a film and usually do. Remixing of film songs with modern beats and rhythms is a common occurrence today, and producers may even release remixed versions of some of their films' songs along with the films' regular soundtrack albums. The encounter between these traditional forms of music and theatre and the technological progress made by Western Cinema is a unique phenomenon in the history of the Seventh Art - the fact that the Indian talkie film is as much a descendant of the expression of 'silent cinema', as that of the musical and theatrical traditions of many centuries.

The dancing in Bollywood films, especially older ones, is primarily modeled on Indian dance: classical dance styles, dances of historic northern Indian courtesans, or folk dances. In modern films, Indian dance elements often blend with Western dance styles (as seen on MTV or in Broadway musicals), though it is not unusual to see Western pop and pure classical dance numbers side by side in the same film. The hero or heroine will often perform with a troupe of supporting dancers. Many song-and-dance routines in Indian films feature unrealistically instantaneous shifts of location and/or changes of costume between verses of a song. If the hero and heroine dance and sing a pas de deux, it is often staged in beautiful natural surroundings or architecturally grand settings. This staging is referred to as a "picturisation".

Songs typically comment on the action taking place in the movie, in several ways. Sometimes, a song is worked into 
the plot, so that a character has a reason to sing. Other times, a song is an externalization of a character's thoughts, or presages an event that has not occurred yet in the plot of the movie.

3 Idiots (2009) an Indian film directed by Rajkumar Hirani started with the song Baheti Hawa Sa Tha Wo in association with the point of view of the narrator, Farhan Qureshi, telling a story of him and also a great friend he and Raju knew from university.

The aesthetics of Indian cinema are mostly the singing and dancing part, the Indian traditional costumes, the traditional ritual ceremony, and the typical plot of rich meets poor, distinct dominance, and etc. 3 Idiots is not an exception to it. In "3 Idiots", there are scenes of songs and dancings, which are significant in Indian cinema, When Pia falls for Ranchoo, she imagines herself singing "Zoobie Doobie" and dancing in duet with Rancho. Meanwhile, having a group of dancers dancing the classical or folk dance with the main character(s) is also a signature part of Indian films.

The Indian costumes are also the important part of Indian films. In India, even though western style of contemporary clothing like gowns, jeans, shirts tops can be seen in most Indian films, due to the influential of western culture, Indian film producers still maintain their traditional clothing for some scenes, and contemporary film like ' 3 Idiots' is no exception. Indian traditional clothing is essential as different types of clothing represent the status and ethnicity of a person. Traditional clothing is also essential for different types of rituals, like wedding ceremony or funeral. For example, when the real Rancho is mourning the death of his father together with his family members and friends, they all wear pale white clothing during the funeral. Another example would be, when Pia is getting married, she wears traditional Indian wedding dress instead of western style of wedding gown.

In a nutshell, the whole film is satire on Indian educational system and also common society thinking. 3 Idiots presents a story which is very much different from other Bollywood films by putting the "problems" on the screen.

3 Idiots presents the "cruel" side of the reality on how people lost their enthusiasm, freedom or even their lives for something, just because of the social norms, educational system and also the economy.

For example, Farhan's father insists Farhan to study Engineering while Raju as the eldest son in the family has to bear the responsibility of taking care of the family by studying hard and earn a lot of money for the family, which make the whole film very close to reality.

The popularity of the film has not waned till this date. In the songs of 3 idiots dance numbers there are two sad songs. First introductory song does not have the accompaniment of dance. All Izz Well is an extravaganza in singing and dancing, it is an open male song Zoobi Doobi is a duet in which there is the combination of traditional and modern singing and dancing. The star cast in particular. The four students, Raju, Farhan, Rancho, Chatur and three members of Dr Viru's family which include his two daughters Mona and Dr. Pia. Aamir Khan, R. Madhavan and Sharman Joshi, Omi Vidya, Mona Sing and Kareena Kapoor have displayed their histrionic elements, the musical score for the songs and the two dances and the background music are superb. The lyricist for all the songs is Swanand Kirkire while the music composer is Shantanu Moitra. The other three important members of the technical team from the department of photography, editing and script writing have contributed fully to making it an interesting film retaining the elements of common public. That is why this is the third film in succession by Rajkumar Hirani which has brought laurels to him and his associates on the creation of this rare diamond in this dark mine of ordinary Hindi films pertaining to Bollywood.

\section{Conclusion}

In the light of the analysis undertaken of the film adaptation entitled '3Idiots', It could be concluded that the aesthetics of Indian Cinema constitutes of features like 'Singing and Dancing', 'Use of Traditional Costumes' and 'Display of Indian Rituals'. All is studded with the typical plot where 'the rich' meets 'the poor' and the display of Romance on the part of the Protagonist moving through the spectacularly enchanting dream sequence with the 'retro' element of the use of Song and Dance. In no way the film adaptation entitled 3Idiots proves to be an exception all this. Moreover, Semiotic Analysis of the Film as a text helps the readerviewer to go beyond the source text by reaching up to the newer and newer layers of meaning simultaneously. It could be finally concluded that the exercise of active creation of meaning reached through the complex interplay of Codes or Conventions becomes inherently fascinating and intellectually empowering.

\section{References}

[1] Chandler, Daniel (2003) Semiotics The Basics. London: Routledge.

[2] Ciecko, A.T. (2006) Contemporary Asian Cinema, New York: Oxford International Printing Ltd.

[3] Courtney, D. (2012) Bollywood Dance. Retrieved from http://chandrakantha. com/articles/indian_music/nritya/bollywoo d.html

[4] Dawyer, Rachel (2015). About-10 bollywood romantic films Retrieved from http://www.bfi.org.uk/news-opinion/newsbfi/lists/10-great- bollywood-romances

[5] Goswami, N (n.d.). The Empire Sings Back: Asthetics, Politics and Postcolonial Whimsy. Retrieved from http://www.contempaesthetics.org/newvol ume/pages/ article. php? articleI $\mathrm{D}=545$

[6] Lovgren, S. (2004). Bollywood: Indian Films Splice. Bombay, Hollywood. 
[7] Manon De Reeper, About-How to Analyse Movies \#2: Signs, Codes \& ConventionsRetrieved fromhttps://www.filminquiry.com/analysemovies-signs/ on 2nd May 2018 at 09.52 $\mathrm{pm}$

[8] Shuman, Leong (2014) FILM STUDIES The Three Idiots Strike Back [Blog Post] Retrieved from http://suesfilmstudiestwo.in/2014/08/thethree-idiots-strike-back.ntml

[9] Three Act Narrative Structure (n.d.). Retrieved August 20, 2014, from http://www.indiana.edu/ audioweb/T206/t hree-act.html

[10] Retrieved August 19, 2014 from http://news.nationalgeographic.com/news/ 2004/01/0121_040121_bollyw oodfilms.html 